\title{
A Project-Based Learning into Flipped Classroom for ePUB3 Electronic Mathematics Learning Module (eMLM)-based on Course Design and Implementation
}

\author{
Rahmi Ramadhani*, Yulia Fitri \\ Department of Informatics, Universitas Potensi Utama, Indonesia
}

Received March 2, 2020; Revised April 22, 2020; Accepted April 29, 2020

Copyright $(2020$ by authors, all rights reserved. Authors agree that this article remains permanently open access under the terms of the Creative Commons Attribution License 4.0 International License

\begin{abstract}
This study aims to develop an electronics mathematics learning module (MLM) using SIGIL software in the form of ePUB3 which can be used to improve the statistical thinking skills of high school students in Medan, North Sumatra, Indonesia. This research is a research and development $(R \& D)$ study with an ASSURE design model consisting of 6 stages, including analyzing learners, state objectives; select methods, media and materials; util media and materials; require participant learner; evaluate and revise. At the product validation stage, ePUB3-eMLM can be applied in mathematics learning in the field. The results of the development of ePUB3-eMLM are implemented to three high schools with cluster types: accreditation school A, accreditation school $\mathrm{B}$ and accreditation school $\mathrm{C}$. The implementation of ePUB3-ebook mathematics uses a flipped classroom model combined with a project-based learning model in the face-to-phase phase face learning. Based on the results of the development and implementation, it is obtained that ePUB3-eMLM that has been developed is valid and effective in improving the statistical thinking skills of high school students in Medan, North Sumatra, Indonesia.
\end{abstract}

Keywords Project-based Learning, Flipped Classroom, Electronics Mathematics Learning Module (eMLM), ePUB3

\section{Introduction}

The use of technology in learning in schools is no longer a new thing. The existence of technology is one of the demands that must be applied by the teacher in the learning process both in the classroom and outside the classroom. Technology has become part of the learning process itself. This makes the teachers have to learn how to integrate technology in every aspect of learning to change the learning strategies and approaches they have done so far [1]. Technology ultimately becomes the focus of the attention of the teachers so that the learning process that will be carried out not only makes technology a learning tool but also provides space for technology to act as learning content to the learning system or curriculum itself [2]-[5]. The presence of technology provides a variety of innovative changes in learning practices. Technology provides a new perspective on the world of education to provide an important role in the creation of new learning methods. The presence of technology in learning also impacts on teachers and students who are important components in the learning process [2]. Various integration of technology in learning has a positive impact in improving the quality of learning, including students more knowledgeable and skilled in using technology in the learning process both in the classroom and outside the classroom. Students' knowledge and skills in applying technology are not only useful in the learning process in the classroom, but also provide an important foundation in solving problems in everyday life [2], [6], [7]. One application of technology in the learning process is teaching material.

The use of technology-based teaching materials provides a flexible space for both teachers and students to explore knowledge gained through the learning process that is not limited by time and place. The technology-based teaching material developed by researchers is the electronics mathematics learning module (eMML). The Electronics Mathematics Learning Module (eMLM) is a digital-based mathematics learning module that can be used either via a PC, Laptop or through an Android or IOS mobile phone. eMLM is one 
of the mathematics teaching materials that contain mathematics teaching material, mathematical problems to guide student activities in solving it in the form of text, audio, until the learning video can be opened and studied directly by students and teachers anywhere and anytime [8]. Digital technology-based teaching materials are developed in accordance with the relevance of the curriculum and the development of learning issues and trends that are being applied. It aims to replace traditional learning towards future learning that has been integrated with digital technology.

Development of eMLM teaching materials is done by using SIGIL software with ePUB3 format. EMLM teaching materials are designed from cover, glossary, preface, sub-chapter of each material, material presented via video which is also described in the form of text, and evaluation of learning activities per sub-chapter material. The development of technology-based learning is not only focused on the development of technology-based teaching materials such as eMLM, but also integrated in learning methods that will be used in the learning process. Learning methods that integrate learning projects in the learning process are project-based learning [9], [10]. The implementation of project-based learning integrated in digital-based learning makes this learning method collaborate in the digital learning phase, namely blended learning with the type of flipped classroom. The collaboration between project-based learning and flipped classroom methods is expected to improve students' statistical thinking skills, especially in statistical material using ePUB3 eMML that has been developed.

\section{Literature Review}

\subsection{Teaching Materials Integrated with Technology}

Teaching materials are materials used by teachers to implement teaching materials in the learning process in the classroom [11]. Teaching materials are divided into several types namely printed teaching materials and non-printed teaching materials. Printed teaching materials consist of modules, handouts and worksheets; while non-printed teaching materials consist of reality teaching materials, teaching materials developed from simple materials, display silent teaching materials, audio, video, overhead transparencies (OHP) [12]. In this study, teaching materials that combine printed teaching materials and non-printed teaching materials, namely modules that are developed digitally and consist of video and audio-based teaching materials. The teaching material is termed as electronics mathematics learning module (eMLM). E-modules are developed specifically for teaching material in learning mathematics. The selected teaching material is statistical teaching material for grade XI students of high school level.
Along with the development of the era, teaching materials are also experiencing growth from traditional based teaching materials (made from printed or audio-based audio or cassette-based) to digital technology-based teaching materials. The development of technology-based teaching materials has differences in explanation and terminology such as internet-based learning, website-based learning or online learning, network-based learning or distance learning. Digital technology-based teaching materials are defined as teaching materials designed in the form of digital media (both in the form of images and text) through the internet and the content contained in teaching materials to the use of learning methods and strategies used are also designed to improve student learning processes and aim to increase the effectiveness of learning to provide knowledge, skills to new experiences for students and teachers [13], [14]. The traditional learning process (teacher-centered learning) does not provide space for technology to be applied in the learning process in the classroom. If used in the traditional learning process, technology only plays a role in learning media that helps teachers in carrying out the traditional learning process in the classroom without providing innovation to the learning methods or strategies. Participation provided by students was not significant because learning focused on the teacher's role as an information center. Teachers who use traditional learning methods do not expect the presence of technology in learning innovation. When technology plays a role in the development of teaching materials in the learning process, the attitudes of teachers who are accustomed to the traditional learning process will find it difficult to implement these technology-based learning innovations [15].

Technology-based teaching materials support information processing by helping students develop mental representations through the incorporation of media elements (whether text, images, videos or audio) that are presented to students. Research related to the use of technology-based teaching materials has shown more positive results to students, this is because students will be accustomed to learning through effective teaching materials by combining text, video or audio-based media rather than just retrieving information through text-based teaching materials alone or audio based only [16]. However, one aspect that must be considered before introducing technology to applying technology-based learning to students is to look at the aspect of acceptance from the student's own side. It is important to do so that the goal of learning is obtained, namely the successful use of technology in the learning process to provide an increase in student learning outcomes [17]-[19].

\subsection{Electronic Mathematics Learning Module (eMLM)}

Modules are teaching materials that are arranged 
systematically with the aim of achieving a certain level of competence as well as the specific learning objectives expected in the curriculum. The right module is a module which is compiled based on three components which are in accordance with the Indonesian National Education Standards Board (BSNP) which is one of the indicators of eligibility that is seen both in terms of language use, material content to presentation and appearance. The preparation of the module also provides a focus on learning that is human in nature and can increase the activeness of students in the learning process in the classroom [20].

Modules in digital learning are arranged in the form of electronic modules or can be abbreviated with e-modules. The e-module developed in this study is the e-module which is applied in the process of learning mathematics, which is hereinafter known as the electronic mathematics learning module (eMLM). Referring to this, the content in eMLM is one of the mathematics learning material which in this case is statistical material. eMLM will be compiled using the SIGIL ePUB3-based application that is designed to be accessible both via laptops, PCs and mobile phones both Android-based and IOS-based. SIGIL-based eMLM ePUB3 presents modules that can record videos, show how to solve mathematical problems and make the process easy for students to learn again, so students will be motivated to learn more. SIGIL ePUB3-based eMLM can also be integrated with digital classroom facilities through Learning Management System and virtual classroom-based learning [21].

\subsection{Project Based Learning into Flipped Classroom}

Digital-based learning provides opportunities for students to further explore skills and enhance student activities in the learning process. Individual understanding to collaboration with peers is expected to provide an increase in student mathematics learning outcomes themselves. In order for the learning process to produce effective and efficient learning, appropriate models, methods and learning strategies are needed. Project based learning is learning that focuses on the process of exploring authentic problems and designing structured problem-solving processes. Project based learning was chosen with the aim that students obtain meaningful learning caused by the learning process that involves activities and interactions between students and their peers. Project based learning or also known as PjBL is also a learning method that helps students to develop their abilities and knowledge in investigating a problem to be able to find a solution to the problem so that it can actualize problems in the real world [22]-[24].

Based on the definition of $\mathrm{PjBL}$ that has been described above, we obtain several aspects that are the most important part in the learning process using the $\mathrm{PjBL}$ model as follows:
- The most important characteristic in implementing $\mathrm{PjBL}$ is independence. Students can take the steps needed in solving problems independently to bring up the potential to solve various more complex problems and provide value to the student's personal learning experience. However, in the project finding solutions to the problem, the teacher still guides and directs students to get the right solution when students still need assistance in the process of discovery.

- Another important characteristic is multidisciplinary science. Through project-based learning, students can use a mathematical approach to find other problems and provide new learning experiences for students that each field of science has a connection with one another.

- The ultimate goal of this $\mathrm{PjBL}$ is to provide new experiences for students in finding their own solutions from the problems presented to be able to create new solutions through the steps of discovery made[25].

In the digital-based learning process, a combination of learning models is needed. Learning is not only entirely centered on direct student activity projects but also combined with digital learning. Combining this learning model is also called blended learning. Blended learning itself is learning that combines face-to-face learning based on digital learning. One type of blended learning chosen in the implementation of the SIGIL ePUB3-based eMLM developed was flipped classroom. Flipped classroom itself is learning that combines learning models in two stages, where the first stage is the face-to-face learning stage and the second stage is the digital learning stage (digital learning or e-learning [3]. Traditional learning, face-to-face learning that is used is a project-based learning model. At the digital technology-based learning stage, eMLM is used and designed using SIGIL with the ePUB3 format which contains statistical teaching material.

\subsection{Statistical Thinking Ability for Senior High School Student}

One of the high order thinking skills (HOTS) is the ability to think statistically. The ability to think statistically is part of the means of scientific thinking in which there is a part of logical and systematic thinking. By mastering the concepts of statistical thinking, it will help students in understanding mathematics [26]-[28]. The development of statistical thinking skills can be done through the provision of learning in statistical material. Statistical learning is very important to be taught in high school learning, this is because the use of statistics is found in solving everyday problems, and can improve statistical thinking skills and other mathematical abilities, such as problem solving skills and critical thinking skills 
as well as the ability to compile appropriate statistical data with the rules to the impact on the development of high school students' character [29]-[32]. The statistical thinking process consists of four stages abbreviated as DORA, including; 1) Describing Data Displays (D); 2) Organizing and Reducing Data (O); 3) Data Representing (R); and 4) Analyzing and Interpreting Data (A) [33].

\subsection{Statistics Teaching Material}

One of the mathematics teaching material that be taught to senior high schools' students based on Indonesian curriculum is statistics. Statistics is a teaching material for eleventh-grade students. There are three parts in this teaching material, such as central tendency, percentile values, and dispersion measurement. Statistics teaching materials are taught in 10 meeting times, for each meeting time, there are two times for the face-to-face learning process and two times for the e-learning process. This first and second meeting, students learn about the introduction of descriptive statistics and how to arrange a distributive frequencies table. The third and fourth meeting, students learn about the central tendency (single data and group data). In this section material, the students learn about mean, median and modus for single and group data. The fifth and sixth meeting, students learn about percentile values, such as quartile values, decile values and percentile values. The seventh and eight meetings, student learn about dispersion measurements, such as range, quartile deviation, mean differences, variance, and standard deviation. The ninth and ten meetings, students learn about histogram and ogive.

This material is one of the problematic materials because students have difficulty on presenting figures or diagrams as well as doing abstract calculations. The measures of the central tendency concept are among the statistical concepts which students often have difficulty learn [34]. A goal of education in statistics is to encourage a positive attitude to statistics as well as to improve student statistical comprehension [35]. Based on this problem, researcher interest to develop the mathematics teaching material (statistics material) in a new style and new look, and we hope the student still exciting and help to learn statistics material. This teaching material will be developed in the electronic mathematics learning module (eMLM). This teaching material will be developed with SIGIL software, and students get a new experience when they study with this new material module.

\section{Methods}

This study uses a type of research development (Research \& Development / R \& D) with the ASSURE design model which consists of 6 stages, including analyzing learners-state objectives; select methods; media and materials; utilize media and material; require participant learner; evaluate; and revise [36]. The stage diagram of the ASSURE design model can be seen in the figure 1: 


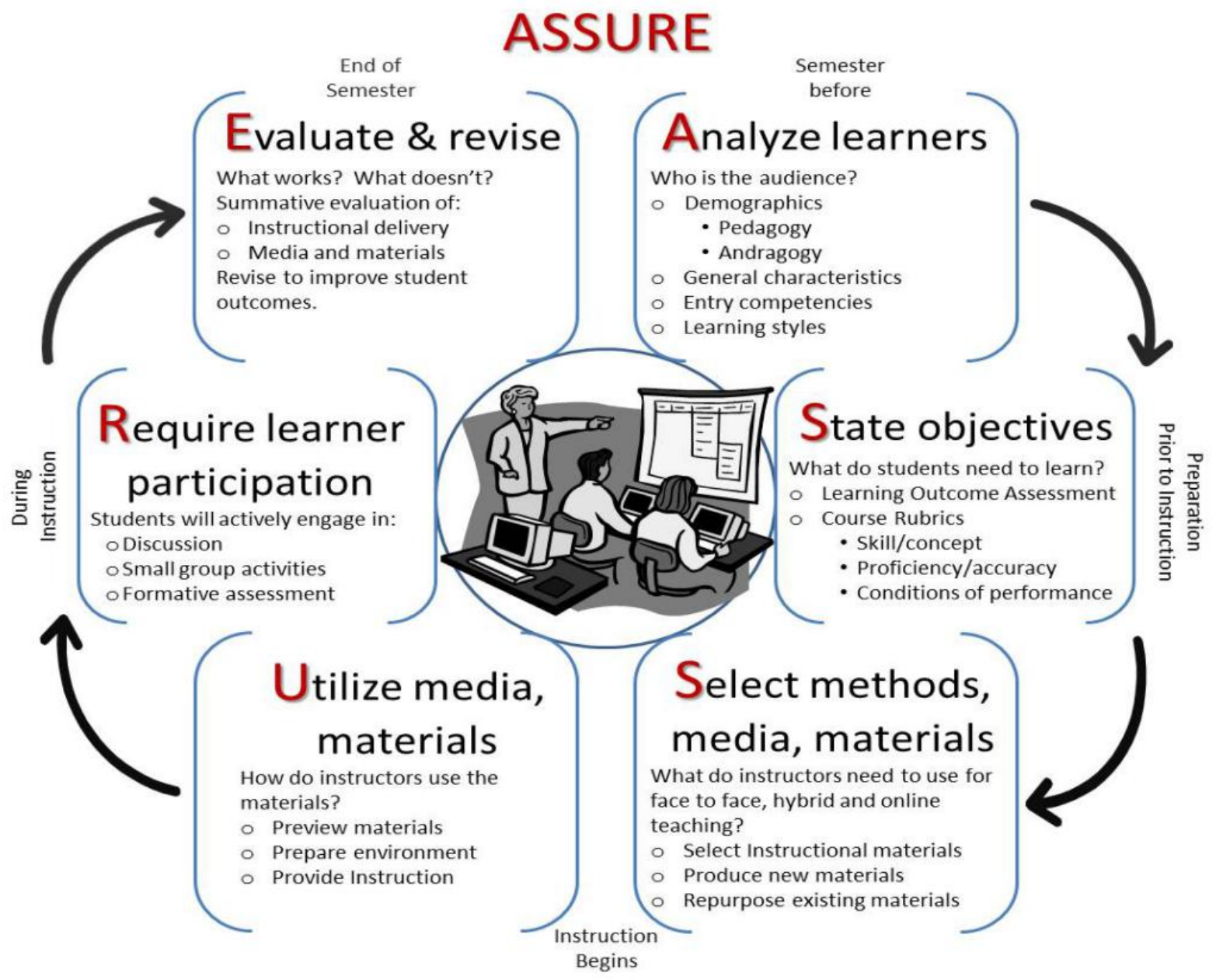

Figure 1. Stages of the ASSURE design model

Stages of developing SIGIL ePUB3-based eMLM using the project-based learning model to flipped classroom or can be termed project-flipped classroom can be seen in the figure 2: 


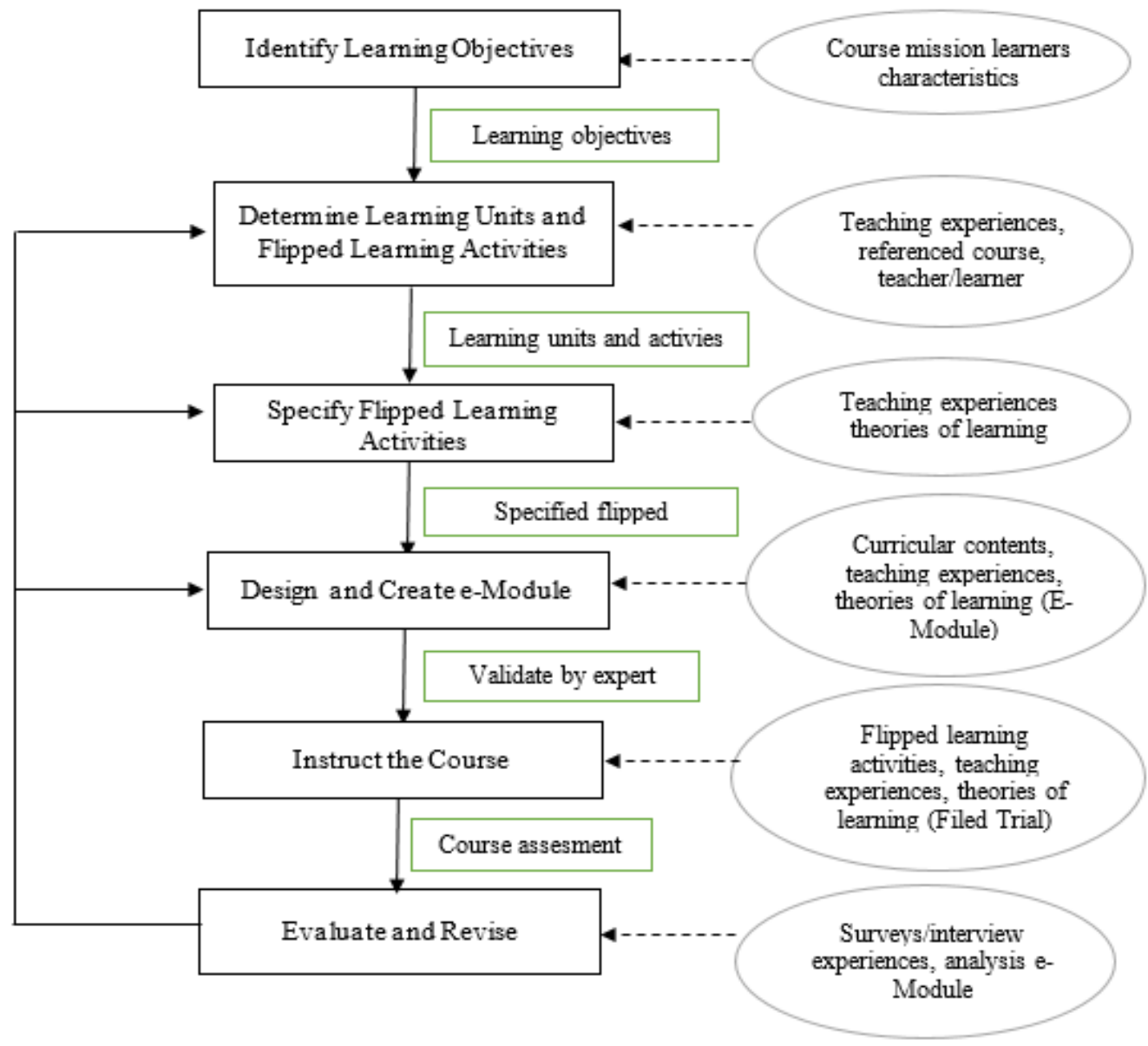

Figure 2. Stages of development of eMLM based on SIGIL ePUB3

The results of the development of the SIGIL ePUB3-based eMLM were further tested for their effectiveness in the learning process at three high schools in the city of Medan. The selection of high school samples is based on the school accreditation ranking used in the education system in Indonesia. The three sample high schools are distinguished from high school with A accreditation, high school with B accreditation and high school with $\mathrm{C}$ accreditation. Samples using project-flipped classroom-based learning using SIGIL ePUB3 based eMLM are senior high schools with A accreditation, this is based on the availability of supporting facilities in implementing digital based learning. This sample is categorized as an experimental class 1 . High school with accreditation B uses project-based learning which focuses on student activities as the main step in improving students' statistical thinking skills. This sample is categorized as an experimental class 2 . While high school with $\mathrm{C}$ accreditation uses traditional learning where the teacher's role is central in the learning process. This sample is categorized as a control class (comparison class). The selection of the three samples with each different treatment model is expected to be a comparison of the application of learning models which are more effective in improving students' statistical thinking skills. Apart from that, the final goal of this research is whether the development of eMLM based on SIGIL ePUB3 gives increased effectiveness in the learning process in the classroom or not.

At the implementation stage, researchers used a quasi-experimental type of research with a type of pre-test post-test control group design. The implementation phase is also expected to be a further analysis of whether there is an interaction between the implementation of project-flipped classroom using SIGIL ePUB3-based eMLM in improving the statistical thinking skills of high school students as seen from the gender of students.

The gender factor is chosen because early studies still exist concerning gender role in the learning of mathematics. Some of the previous research found that females tend to earn higher grades than males in mathematics. Females were found not to believe in stereotypes mathematics firmly is not their subject, while male counterparts are not a strong stereotype for male domain mathematics [37]. On the other hand, Collen Ganley and Sarah Lubienski in their research found that boys and girls score equally on many state tests, both primary and secondary, and in math classes, girls get 
really good grades. However, gender differences in mathematics and skills appear in elementary school and, in fact, boys in a number of key math fields, such as engineering and computer science, are much more likely to pursue careers than girls [38]. The review shows that many factors may relate to gender differences, such as interaction in classrooms, attitudes of the students, student interest and self-esteem, gender attitudes of teachers, curricula, beliefs and social and cultural norms. These differences have consequences for the types of instructional procedures to be taken to set up a suitable teaching and learning environment for mathematics training suited to both sexes [39], [40]. In this study, the choice of sex as the interaction variable is based on current world trends and the focus of research on gender issues.

\subsection{Samples}

The sample in this study were second-level students in high schools in the City of Medan, North Sumatra, Indonesia. Participants in this study came from three different high schools and were selected through the cluster sampling method by looking at the ranking of schools based on accreditation (accreditation A, B and C). The number of participants in this study were 105 students. 35 students in class 1 experiment will be taught using the project-flipped classroom model using SIGIL ePUB3-based eMLM that was developed previously; 35 students in the experimental class 2 will be taught using the project-based learning (PjBL) learning model; and 35 students in the control class will be taught using conventional learning models. Participants in this study are second-year students at High Schools, who have an age range of 15-17 years. The selection of students in this range is due to the age range of the student is already at the level of formal operations (11 years and above) in accordance with the cognitive development theory developed by Piaget. In the period of formal operations, students are at the peak level of development of cognitive structures, where students are able to think logically for all kinds of hypothetical problems, verbal problems, and can use scientific reasoning and can accept the views of others [41], [42]. This study also looked at the interaction between the gender of students (male and female) with the implementation of eMLM based on SIGIL ePUB3 using the project-flipped classroom model.

\subsection{Data Collection}

The research data were obtained from the pre-test and post-test results in each learning class (experimental class 1, experimental class 2 and control class). The test given is an essay test which consists of five questions and is related to statistical material. In addition to passing the test, the research data were also collected through a SIGIL ePUB3-based eMLM questionnaire using the project-flipped classroom model. Data were analyzed using descriptive statistical tests (mean and standard deviation), as well as using the Two-way ANOVA inferential statistical test and the Post Hoc-LSD test to see how much influence the treatment of learning models had on student learning outcomes (especially on increasing indicators of statistical thinking ability), and to see how much gender interacts with the ability to think statistically as well as differences in interactions between students' gender. The results of the study were analyzed using SPSS 25.0 statistical tools with a statistical significance of 0.05 level with two tails tests. To test the homogeneity of the data used the Kolmogorov-Smirnov Test and to test the normality of the data, the Levene Test of Quality was used.

\section{Results and Discussion}

\subsection{Design Phase}

At this design stage, eMLM that has been prepared and created using the SIGIL application platform with ePUB3 format is entered at the validation stage by experts (experts), both experts in the field of teaching materials and experts in the field of technology-based teaching materials innovation. The results of expert validation obtained that eMLM that has been developed is feasible or valid to be applied in the learning process in the classroom. The following eMLM display is designed using SIGIL in figure 3: 


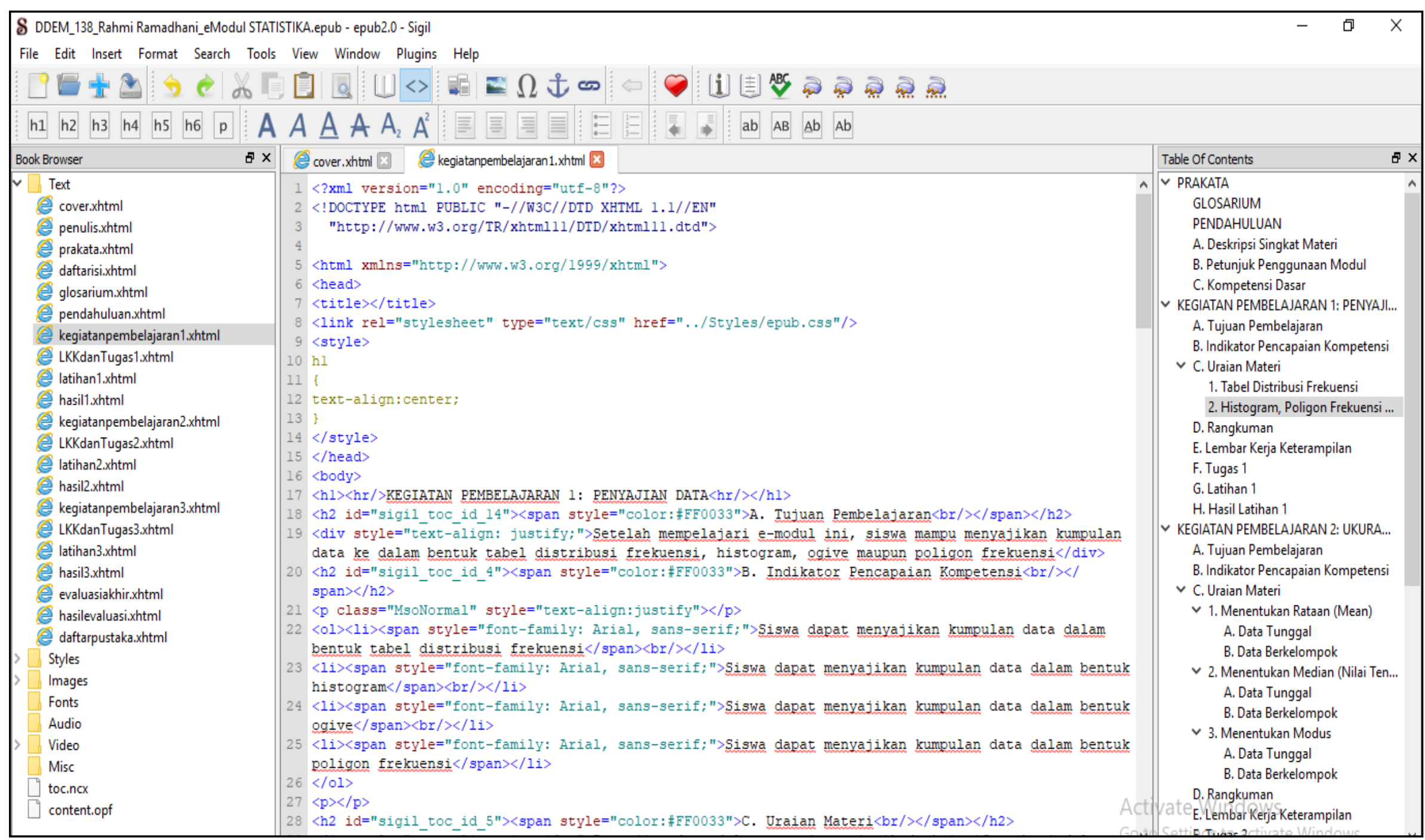

Figure 3. Display of eMLM in SIGIL

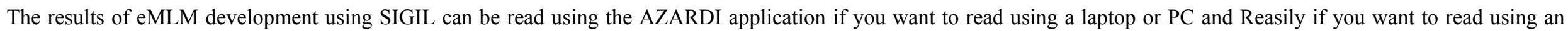
Andorid-based handphone. The following eMLM in figure 4 until 6 can be read with ePUB reader applications, namely AZARDI. 


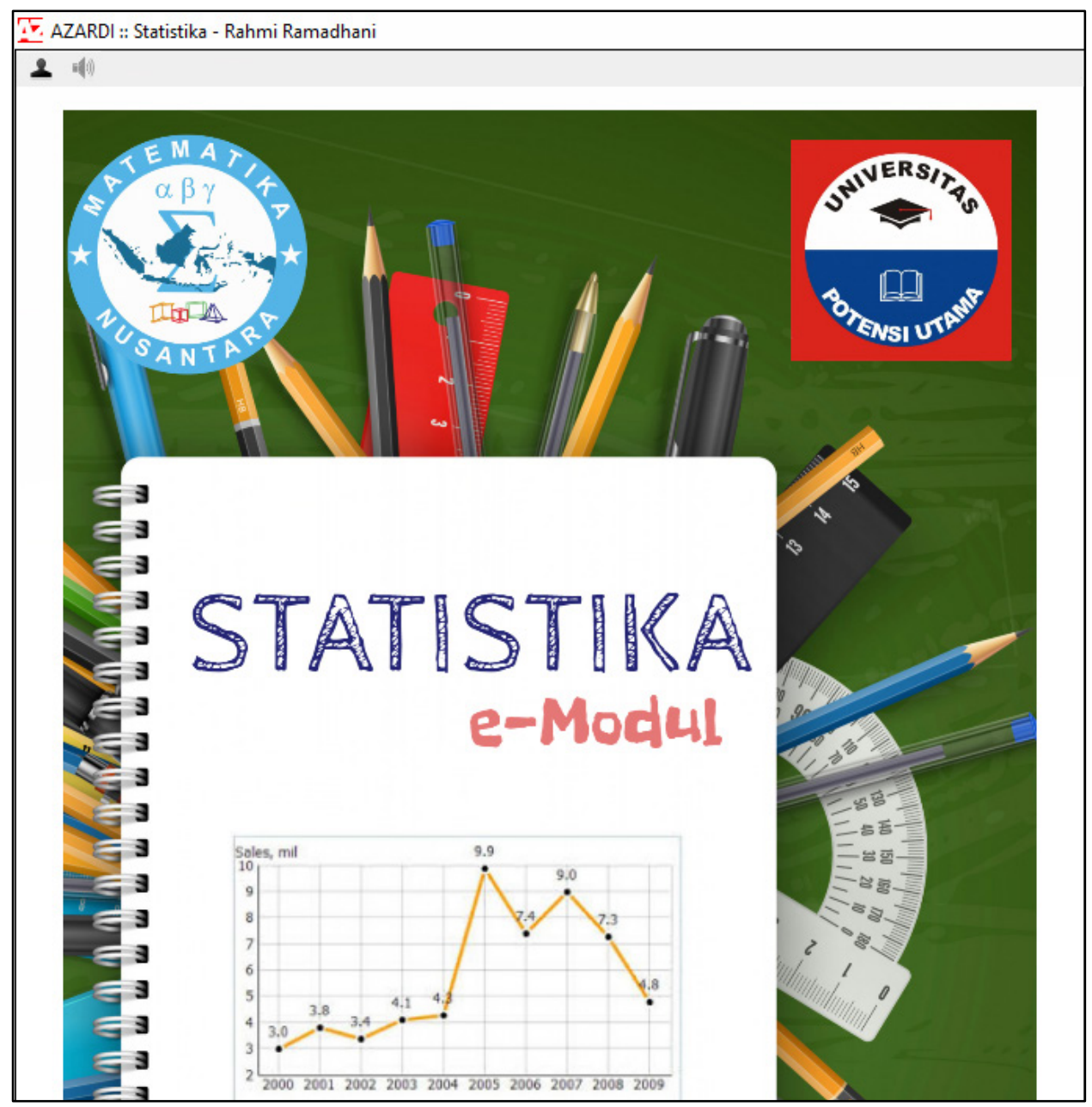

Figure 4. Cover eMLM that has been developed 


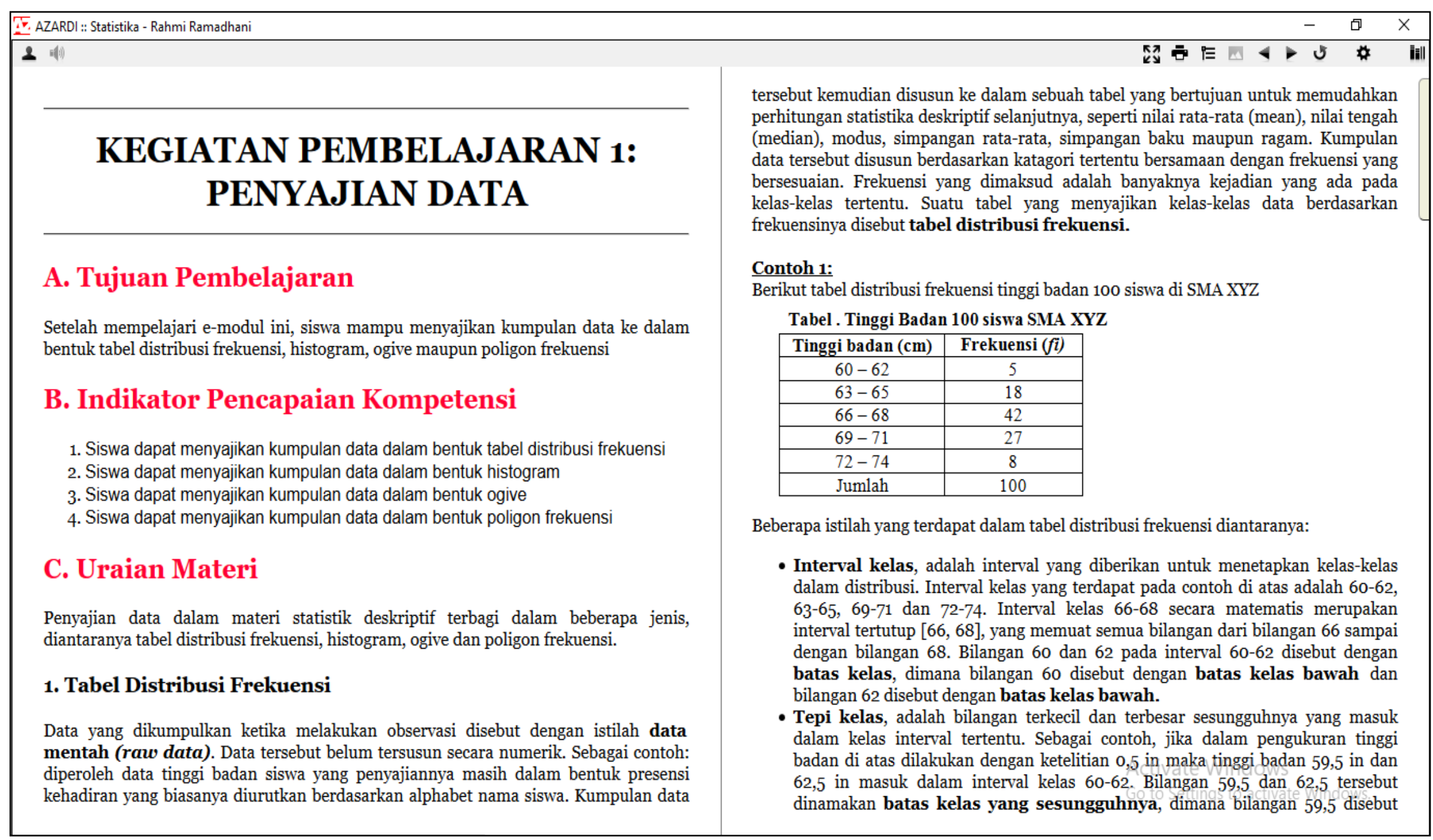

Figure 5. Display Learning Activities contained in eMLM that are read with AZARDI 


$\begin{array}{lll}21: 07 & \text { Statistika } \\ \text { Rahmi Ramadhani } & \text { Q }\end{array}$

\title{
KEGIATAN \\ PEMBELAJARAN 1: PENYAJIAN DATA
}

\section{A. Tujuan Pembelajaran}

\begin{abstract}
Setelah mempelajari e-modul ini, siswa mampu menyajikan kumpulan data ke dalam bentuk tabel distribusi frekuensi, histogram, ogive maupun poligon frekuensi

\section{B. Indikator Pencapaian Kompetensi}

1. Siswa dapat menyajikan kumpulan data dalam bentuk tabel distribusi frekuensi

2. Siswa dapat menyajikan kumpulan data dalam bentuk histogram

3. Siswa dapat menyajikan kumpulan data dalam bentuk ogive

4. Siswa dapat menyajikan kumpulan data dalam bentuk poligon frekuensi

\section{Uraian Materi}

Penyajian data dalam materi statistik deskriptif terbagi dalam beberapa jenis, diantaranya tabel distribusi frekuensi, histogram, ogive dan poligon frekuensi.

\section{Tabel Distribusi Frekuensi}

Data yang dikumpulkan ketika melakukan observasi

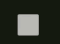

O

4

Figure 6. Display Learning Activities contained in eMLM that are read with Reasily

Table 1. Description of student learning outcomes in the experimental and control classes

\begin{tabular}{cccccc}
\hline \multicolumn{7}{c}{ Descriptive Statistics } \\
\hline & N & Minimum & Maximum & Mean & Std. Deviation \\
\hline Pre_Test_Experiment_1 & 35 & 45.00 & 80.00 & 59.3143 & 8.42186 \\
\hline Post_Test_Experiment_1 & 35 & 68.00 & 90.00 & 78.1714 & 5.18190 \\
\hline Pre_Test_Experiment_2 & 35 & 40.00 & 70.00 & 58.0286 & 7.81960 \\
\hline Post_Test_Experiment_2 & 35 & 65.00 & 85.00 & 74.6857 & 4.85539 \\
\hline Pre_Test_Control & 35 & 35.00 & 70.00 & 51.1143 & 9.11615 \\
\hline Post_Test_Control & 35 & 55.00 & 80.00 & 70.6571 & 5.74939 \\
\hline Valid N (listwise) & 35 & & & & \\
\hline
\end{tabular}




\subsection{Implementation Phase}

At the implementation stage, eMLM that has been developed is then used in the learning process in the classroom. After eMLM is used in the learning process, an analysis of the results of the statistical thinking ability has been calculated which has been obtained through the provision of pre-test and post-test in each learning class. The results of the analysis of the pre-test and post-test scores on students' statistical thinking skills can be seen in Table 1 above.

Based on Table 1 above, it can be seen that the average value in the pre-test of students in the control class is lower (51.11) than the average value of pre-test students in the experimental class 1 (59.31) and the experimental class_2 (58.03). The same thing is also seen that the average post-test score of students in the experimental_1 class is higher (78.17) than the average post-test scores of students in the experimental class_2 (74.68) and the control class $(70,66)$. Improvement of students 'statistical thinking skills in Statistics teaching materials in the experimental class (both Experiment_1 and Experiment_2) results in a higher increase than the increase in students' statistical thinking skills in the control class. Improved statistical thinking skills can be determined from the difference between the students' post-test scores and the students' pre-test scores divided by the difference in the overall total scores with the students' pre-test scores. The results of the increase are also called the N-Gain normalized Gain [43]. Improved student learning outcomes both in the experimental class_1, experimental class_2 and in the control class can be seen in Table 2 below:

Table 2. N-Gain statistics thinking ability based on student gender

\begin{tabular}{cccc}
\hline \multirow{2}{*}{ Learning_Model } & Gender & Mean & Std. Error \\
\hline \multirow{2}{*}{ Experiment Class 1 } & Male & .461 & .030 \\
\cline { 2 - 4 } & Female & .548 & .031 \\
\hline \multirow{2}{*}{ Experiment Class 2} & Male & .381 & .031 \\
\cline { 2 - 4 } & Female & .416 & .030 \\
\hline \multirow{2}{*}{ Control Class } & Male & .359 & .030 \\
\cline { 2 - 4 } & Female & .296 & .031 \\
\hline
\end{tabular}

In Table 2 above, information is also given about the
NGain value of statistical thinking ability in each gender category of students (male and female) for each learning class. The average NGain value for male gender in the experimental class $1 \quad(0.461)$ is higher than the experimental class_2 $(0.381)$ and the control class $(0.359)$. Likewise for the average value of NGain in female gender, in the experimental class_1 the results obtained were 0.548 higher than the experimental class_2 and the control class namely 0.416 and 0.296 . This can be interpreted that an increase in the ability to think statistically in the experimental class 1 is better than an increase in the ability to think statistically in the experimental class 2 and the control class. The application of SIGIL-based eMLM using the project-flipped classroom model has an effect on improving statistical thinking skills for each student's gender category.

Homogeneity calculation of statistical thinking ability data is also performed using the Kolmogorov-Smirnov Test. Homogeneity test results obtained significance value greater than 0.05 , which is equal to $0.960>0.05 \mathrm{So}$, it can be concluded that the students' statistical thinking ability data using SMLIL eMLM with the project-flipped classroom model has the same or homogeneous variance. The statistical ability of students with the same statistical ability was also tested using the Levene Test of Quality. The results of the normality test of students' statistical thinking abilities obtained a significance value greater than 0.05 in the amount of $0.200>0.05$ (in the experimental class 2 and in the control class) and $0.160>$ 0.05 in the experimental class_1. Based on the above calculation results, it can be concluded that the NGain data on students' statistical thinking abilities are normally distributed.

The NGain data on students' statistical thinking ability is then calculated to see whether there is a significant effect after being taught with SIGIL eMLM using the project-flipped classroom model. Based on the results of the data homogeneity test calculation and the data normality test, it was found that the NGain data of statistical thinking ability is homogeneous and normally distributed data, so the next calculation can be done using the Two Path Analysis of Variance (ANOVA). The results of the Two-Way ANOVA test calculation can be seen in Table 3 and figure 7 : 
Table 3. Results of the two-way ANOVA calculation

\begin{tabular}{cccccc}
\hline Tests of Between-Subjects Effects & \multicolumn{7}{c}{} \\
\hline \multicolumn{7}{c}{ Dependent Variable: NGain_Statistical_Thinking } & & \\
\hline Source & $\begin{array}{c}\text { Type III Sum of } \\
\text { Squares }\end{array}$ & df & Mean Square & F & Sig. \\
\hline Corrected Model & $.653^{\mathrm{a}}$ & 5 & .131 & 8.195 & .000 \\
\hline Intercept & 17.665 & 1 & 17.665 & 1108.806 & .000 \\
\hline Learning_Model & .555 & 2 & .277 & 17.417 & .000 \\
\hline Gender & .010 & 1 & .010 & .651 & .422 \\
\hline Learning_Model * Gender & .101 & 2 & .050 & 3.161 & .067 \\
\hline Error & 1.577 & 99 & .016 & & \\
\hline Total & 19.913 & 105 & & & \\
\hline Corrected Total & 2.230 & 104 & & & \\
\hline a. R Squared $=.293$ (Adjusted R Squared & $.257)$ & & & \\
\hline
\end{tabular}

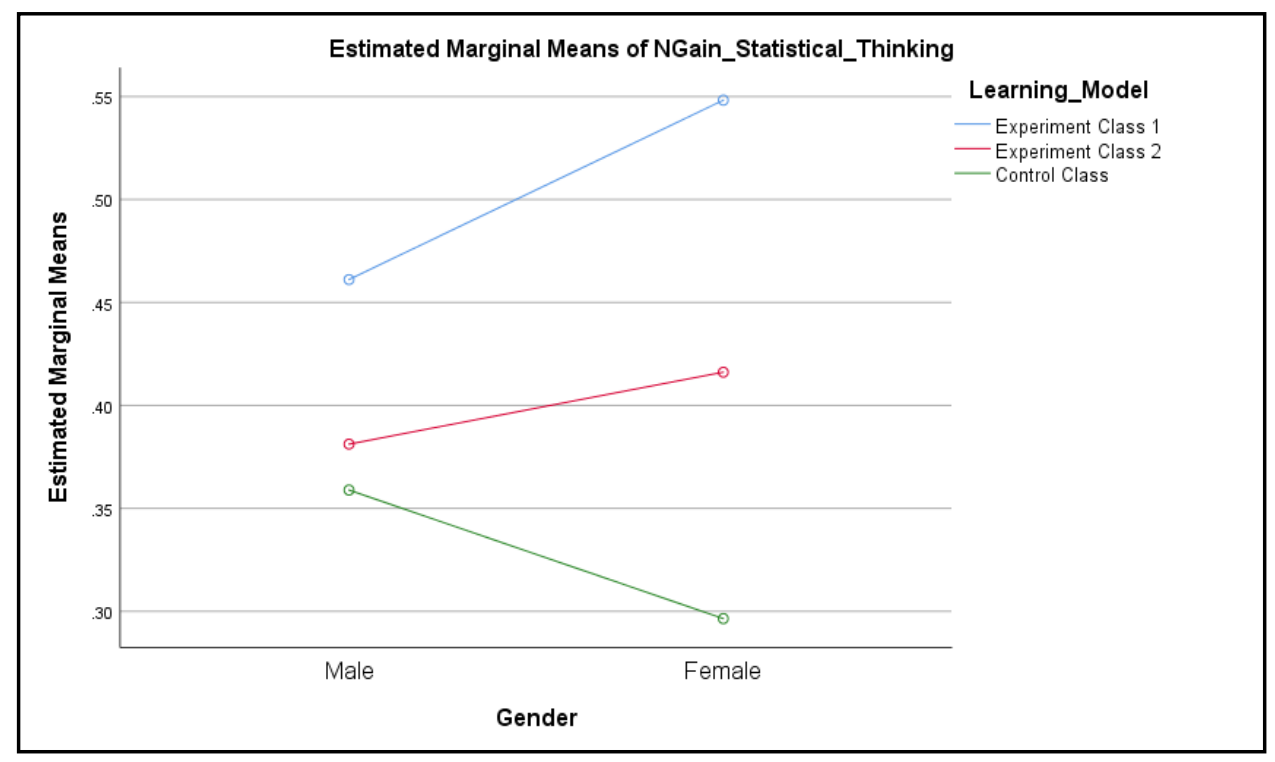

Figure 7. Interaction between students' statistics thinking abilities and gender factors

Based on Table 3 above, it can be seen that the learning class factor obtained an $F$ value of 17,417 with a significant value of 0,000 . Because the significant value is smaller than $0.05(0,000>0.05)$, it is found that $\mathrm{H} 0$ is rejected and $\mathrm{H} 1$ is accepted. So it can be concluded that there is effectiveness and improvement in students' statistical thinking skills taught with SIGIL eMLM using the project-flipped classroom model. To see if there is an interaction between students 'gender factors and students' statistical thinking skills, it can be seen in Figure 7 above.

Based on Table 3 above, it can be seen that the learning class and gender factors obtained an $\mathrm{F}$ value of 3.161 with a significant value of 0.067 . Because the significant value obtained is greater than $0.05(0.067>0.05)$, it is found that $\mathrm{H} 1$ is rejected and $\mathrm{H} 0$ is accepted. So it can be concluded that there is no interaction between student gender factors with students' statistical thinking abilities. The graph of the interaction between students 'statistical thinking abilities and students' gender factors can also be seen in
Figure 7 above. Based on the information provided in Figure 7, it appears that the graphs of each learning class do not intersect, so it can be said that the interaction of statistical thinking abilities with the gender factors of students does not occur. This proves that the increase in students' statistical thinking skills is purely due to the treatment of the project-flipped classroom model by using eMLM that has been developed with the SIGIL application with ePUB3 format in the learning process. The gender factor of students (male and female) has no role in providing an effect on increasing students' statistical thinking skills. In accordance with the analysis in Table 3, that $\mathrm{H} 1$ is accepted or in other words there is effectiveness and improvement of students' statistical thinking skills after being given a model project-flipped classroom treatment using SMLIL eMLM, it is necessary to carry out further analysis of the differences in the gender factors of these students. The follow-up test uses the Post Hoc-LSD Test, and can be seen in Table 4 below: 
A Project-Based Learning into Flipped Classroom for

ePUB3 Electronic Mathematics Learning Module (eMLM)-based on Course Design and Implementation

Table 4. Post Hoc-LSD test results calculation

\begin{tabular}{|c|c|c|c|c|c|c|}
\hline \multicolumn{7}{|l|}{ Multiple Comparisons } \\
\hline \multicolumn{7}{|c|}{ Dependent Variable: NGain_Statistical_Thinking } \\
\hline \multicolumn{7}{|c|}{ LSD } \\
\hline \multirow{2}{*}{ (I) Learning_Model } & \multirow{2}{*}{ (J) Learning_Model } & \multirow{2}{*}{ Mean Difference (I-J) } & \multirow{2}{*}{ Std. Error } & \multirow{2}{*}{ Sig. } & \multicolumn{2}{|c|}{$95 \%$ Confidence Interval } \\
\hline & & & & & Lower Bound & Upper Bound \\
\hline \multirow{2}{*}{ Experiment Class 1} & Experiment Class 2 & $.1043^{*}$ & .03017 & .001 & .0444 & .1642 \\
\hline & Control Class & $.1749^{*}$ & .03017 & .000 & .1150 & .2347 \\
\hline \multirow{2}{*}{ Experiment Class 2} & Experiment Class 1 & $-.1043^{*}$ & .03017 & .001 & -.1642 & -.0444 \\
\hline & Control Class & $.0706^{*}$ & .03017 & .021 & .0107 & .1304 \\
\hline \multirow{2}{*}{ Control Class } & Experiment Class 1 & $-.1749^{*}$ & .03017 & .000 & -.2347 & -.1150 \\
\hline & Experiment Class 2 & $-.0706^{*}$ & .03017 & .021 & -.1304 & -.0107 \\
\hline \multicolumn{7}{|c|}{$\begin{array}{l}\text { Based on observed means. } \\
\text { The error term is Mean Square (Error) }=.016 \text {. }\end{array}$} \\
\hline *. The mean difference $\mathrm{i}$ & nificant at the, 05 level & & & & & \\
\hline
\end{tabular}

Based on Table 4 above, the results show that there are differences in the value of increasing statistical thinking ability (NGain) for each of the learning class categories. The purpose of this study is to see whether eMLM developed using SIGIL with ePUB3 format is effective in improving students' statistical thinking skills using the project-flipped classroom model for high school students divided into three clusters, namely $\mathrm{A}$ accreditation, B accreditation and $\mathrm{C}$ accreditation. Based on the results of the hypothesis calculation test using the Two Path ANOVA test, the analysis results are obtained that the group of students taught using the project-flipped classroom model and SIGIL eMLM (in accreditation A high schools) have an average increase in statistical thinking skills that is better and more significant than with other groups of students (students at SMA B accreditation and students at SMA C accreditation). Through the same calculation also obtained the results that the gender factor of students does not have any role in improving students' statistical thinking skills. This shows the fact that the average statistical thinking ability of students is not influenced by the gender factors of the students themselves. This is consistent with the research fact that gender does not have an influence on students' cognitive improvement both in learning achievement and student motivation in learning [44]-[48].

The main factor that provides an increase in students' high statistical thinking skills is the implementation of SIGIL eMLM using the project-flipped classroom model. The project-flipped classroom model has an influence on student achievement due to the support of constructivism theory which requires students to be active, communicative, creative and can collaborate in learning activities [49]. The effects of project-based learning provide space for student activities freely to develop skills, especially in solving statistical problems logically and structured [50], [51]. The eMLM support that is designed as attractive as possible with graphical displays and learning videos makes it easy for students to learn statistical material and makes it easy for students to conduct self-evaluation tests directly on the eMLM. The ePUB 3 format makes it easy for students to read only by using ePUB reader applications such as AZARDI (on laptops) and Reasily (on Android phones) providing broad access for students without knowing the place and time to access teaching material. The real effect of the use of ePUB3 SIGIL-based mathematical modules with the Flipped-Blended Learning model is to increase students 'motivation, students' independence in this case students in learning mathematics and increase the effectiveness of the learning process [52]-[55].

The implementation of SIGIL eMLM also has an impact on the enthusiasm and motivation of students in following the statistical learning process. Learning activities that combine two different learning environments, namely conventional learning (face-to-face learning) and digital technology-based learning provide new experiences for students. Researchers give questionnaires to students who are taught using the procet-flipped classroom model with SIGIL eMLM, which aims to see how far the effects and personal impact of students in participating in learning activities based on project-flipped classroom. The results of the questionnaire can be seen in figure 8 : 


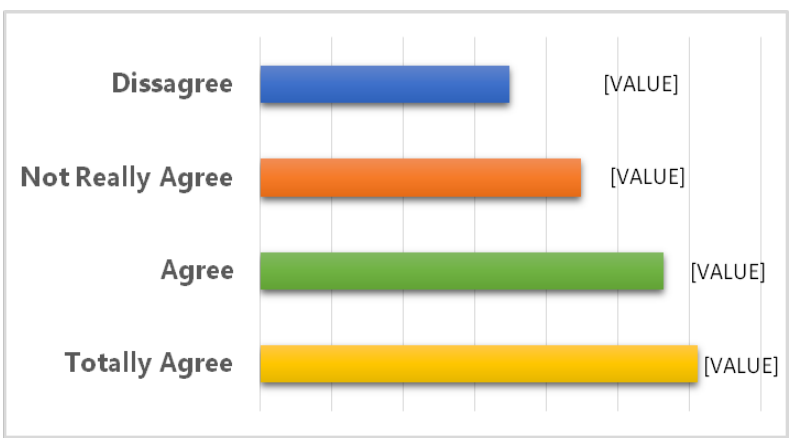

Figure 8. Results of calculation of student questionnaire in experiment class_1

The results of student questionnaire calculations regarding the application of SIGIL eMLM with the project-flipped classroom model obtained an average percentage of questionnaires at a level of percentage of $58.80 \%$ and included in the good categories. Then, based on the results of the percentage of questionnaires that have been obtained, this proves that increasing motivation, enthusiasm and a sense of enthusiasm of students in participating in learning. Through the implementation of SIGIL eMLM with the project-flipped classroom model, it provides new experiences for students and it is proven that the SIGIL ePUB3 eMLM that has been developed is valid and effective in the learning process for high school students.

\section{Conclusions}

Mathematics learning by applying SIGIL eMLM that has been developed and treating the learning model with the type of project-flipped classroom has a real effect in developing the statistical thinking skills of second year high school students in Medan. The development of SIGIL eMLM with the ePUB3 format proved to be valid and effective for use in the learning process with the additional treatment of the project-flipped classroom model for high school students.

\section{Acknowledgements}

Great appreciation and gratitude are due to Ministry of Research and Technology of the Republic of Indonesia (Council of Research and National Innovation)-Deputy of Research Reinforcement and Development that has provided funding this research project (Research of Initiate Lecturer or PDP) with letter of decision No. 9/E1/KPT/2020. Thank you to Rofiqul Umam, Ph.D (Kwansei University Japan) who helped in completing this research.

\section{REFERENCES}

[1] B. G. Jayatilleke, G. R. Ranawaka, C. Wijesekera, and M. C. B. Kumarasinha, "Development of mobile application through design-based research," Asian Assoc. Open Univ. $J .$, vol. 13, no. 2, pp. 145-168, 2018.

[2] T. M. Wong, "Teaching innovations in Asian higher education: perspectives of educators," Asian Assoc. Open Univ. J., vol. 13, no. 2, pp. 179-190, 2018.

[3] R. Ramadhani, R. Umam, A. Abdurrahman, and M. Syazali, "The Effect of Flipped-Problem Based Learning Model Integrated With LMS-Google Classroom for Senior High School Students," J. Educ. Gift. Young Sci., vol. 7, no. 2, pp. 137-158, Jun. 2019.

[4] G. Bozkurt and K. Ruthven, "The activity structure of technology-based mathematics lessons: a case study of three teachers in English secondary schools," Res. Math. Educ., vol. 20, no. 3, pp. 254-272, 2018.

[5] L. Thibaut et al., "Integrated STEM Education: A Systematic Review of Instructional Practices in Secondary Education," Eur. J. STEM Educ., vol. 3, no. 1.02, pp. 1-12, 2018.

[6] R. S. Darma, A. Setyadi, I. Wilujeng, Jumadi, and H. Kuswanto, "Multimedia Learning Module Development based on SIGIL Software in Physics Learning," in IOP Conf. Series: Journal of Physics: Conf. Series 1233, 2019, pp. 1-7.

[7] W. H. Al-Hilli, "Using Software's and Technology in Solving Mathematics Problem to Motivate and Accelerate the Learning Process," EURASIA J. Math. Sci. Technol. Educ., vol. 15, no. 3, pp. 1-6, 2019.

[8] W. D. Dwiyogo, "Developing a Blended Learning-Based Method for Problem-Solving in Capability Learning," TOJET Turkish Online J. Educ. Technol., vol. 17, no. 1, pp. 51-61, 2018.

[9] H. Serin, "Project Based Learning in Mathematics Context," Int. J. Soc. Sci. Educ. Stud., vol. 5, no. 3, pp. 232-236, 2019.

[10] L. A. Jacques, "What does Project-based Learning (PBL) Look like in the Mathematics Classroom?," Am. J. Educ. Res., vol. 5, no. 4, pp. 428-433, 2017.

[11] M. K. Abadi, H. Pujiastuti, and L. D. Assaat, "Development of Teaching Materials Based Interactive Scientific Approach towards the Concept of Social Arithmetic For Junior High School Student," in IOP Conf. Series: Journal of Physics: Conf. Series 812, 2017, pp. 16.

[12] R. Sitohang, "Mengembangkan Bahan Ajar dalam Pembelajaran Ilmu Pengetahuan Sosial (IPS) di SD," $J$. Kewarganegaraan, vol. 23, no. 2, pp. 13-24, 2014.

[13] M.-H. Lin, H.-C. Chen, and K.-S. Liu, "A Study of the Effects of Digital Learning on Learning Motivation and Learning Outcome," EURASIA J. Math. Sci. Technol. Educ., vol. 13, no. 7, pp. 3553-3564, 2017.

[14] A. Syawaludin, Gunarhadi, and P. Rintayati, "Development of Augmented Reality-Based Interactive Multimedia to Improve Critical Thinking Skills in Science 
Learning,” Int. J. Instr., vol. 12, no. 4, pp. 331-344, 2019.

[15] M. Yildiz and Y. Selim, "A Qualitative Study on Transferring The Experience of Using Technology from Formal Education to Distance Education," Turkish Online J. Distance Educ., vol. 16, no. 4, pp. 125-134, 2015.

[16] R. E. Mayer, "Applying the science of learning: Evidence-based principles for the design of multimedia instruction," Am. Psychol., vol. 63, no. 8, pp. 760-769, 2008.

[17] F. M. Zain, E. Hanafi, Y. Don, M. F. M. Yaakob, and S. N. Sailin, "Investigating Student's Acceptance of an EDMODO Content Management System," Int. J. Instr., vol. 12, no. 4, pp. 1-16, 2019.

[18] M. Yeou, “An investigation of students' acceptance of Moodle in a blended learning setting using technology acceptance model," J. Educ. Technol. Syst., vol. 44, no. 3, pp. 300-318, 2016.

[19] S. Sumarni, R. Ramadhani, Y. Sazaki, R. T. Astika, W. D. Andika, and A. E. Prasetiyo, "Development of "Child Friendly ICT' Textbooks to Improve Professional Competence of Teacher Candidates: A Case Study of Early Childhood Education Program Students," J. Educ. Gift. Young Sci., vol. 7, no. 3, pp. 693-708, Sep. 2019.

[20] H. Zulfah and N. Aznam, "Development of Natural Sciences Module with Reflective Learning Journal to Enhance Student's Reporting-Interpretative Skills," Biosaintifika J. Biol. Biol. Educ., vol. 10, no. 2, pp. 362 368,2018

[21] F. J. Muriel and C. Galet, "Editing ePub3 for Blended Learning in Mathematics," in The 2nd Innovative and Creative Education and Teaching International Conference (ICETIC2018), 2018, pp. 1-7.

[22] L. Darling-Hammond, "Teaching and learning for understanding," in Powerful learning: What we know about teaching for understanding, L. Darling-Hammond, B. Barron, P. A. Pearson, A. H. Schoenfeld, E. K. Stage, T. D. Zimmerman, G. N. Cervetti, and J. L. Tilson, Eds. San Fransisco, CA: Jossey-Bass, 2008, pp. 1-8.

[23] J. Larmer, J. R. Margendoller, and S. Boss, Setting the standard for project based learning: A proven approach to rigorous classroom instruction. Alexandria, VA: ACSD, 2015.

[24] S. Kaldi, D. Filippatou, and C. Govaris, "Project-based learning in primary schools: Effects on pupils' learning and attitudes," Educ. 3-13 Int. J. Primary, Elem. Early Years Educ., vol. 39, no. 1, pp. 35-47, 2011.

[25] S. Halverscheid, "Features of mathematical activities in interdisciplinary, project-based learning," Zentralblatt für Didakt. der Math., vol. 37, no. 3, pp. 200-207, Jun. 2005.

[26] R. Ramadhani and S. D. Narpila, "Problem based learning method with geogebra in mathematical learning," Int. J. Eng. Technol., vol. 7, no. 3.2 Special Issue 2, 2018.

[27] R. Ramadhani and S. D. Narpila, "Peningkatan Kemampuan Berpikir Statistik Melalui Problem-Based Learning Berbudaya Lokal pada Siswa Kelas XI SMA YPK Medan,” J. Parad., vol. 11, no. 1, pp. 74-84, 2018.

[28] S. Sharma, "Definitions and models of statistical literacy: a literature review," Open Rev. Educ. Res., vol. 4, no. 1, pp. 118-133, Jan. 2017.

[29] R. Mahdayani, "Analisis Kesulitan Siswa dalam Pemecahan Masalah Matematika pada Materi Aritmetika, Aljabar, Statistik dan Geometri," J. Pendas Mahakan, vol. 1, no. 1, pp. 86-98, 2016.

[30] C. Batanero and C. Diaz, "Training Teacher to Teach Statistics: What Can We Learn from Research?," Stat. Enseignment, vol. 1, no. 1, pp. 5-20, 2010.

[31] E. S. Mooney, "A Framework for Characterizing Middle School Students' Statistical Thinking," Math. Think. Learn., vol. 4, no. 1, pp. 23-63, Jan. 2002.

[32] R. C. delMas, "Statistical Literacy, Reasoning, and Thinking: A Commentary," J. Stat. Educ., vol. 10, no. 2, Jan. 2002.

[33] J. M. Shaughnessy, "Missed opportunities in research on the teaching and learning of data and chance," in Proceedings of the Twentieth Annual Conference of the Mathematics Education Research Group of Australasia, 1996, pp. 6-22.

[34] S. S. Saidi and N. M. Siew, "Assessing Students' Understanding of the Measures of Central Tendency and Attitude towards Statistics in Rural Secondary Schools," Int. Electron. J. Math. Educ., vol. 14, no. 1, pp. 73-86, 2019.

[35] A. K. Liau, J. E. Kiat, and Y. N. Source, "Title Investigating the pedagogical approaches related to changes in attitudes toward statistics in a quantitative methods course for psychology undergraduate students," Asia-Pacific Educ. Res., vol. 24, no. 2, pp. 319-327, 2015.

[36] A. Sharif and S. Cho, "21st-Century Instructional Designers: Bridging the Perceptual Gaps between Identity, Practice, Impact and Professional Development," RUSC. Univ. Knowl. Soc. J., vol. 12, no. 3, pp. 72-85, 2015.

[37] S. Anjum, "Gender Difference in Mathematics Achievement and its Relation with Reading Comprehension of Children at Upper Primary Stage," $J$. Educ. Pract., vol. 6, no. 16, pp. 71-75, 2015.

[38] C. Ganley and S. Lubienski, "Current Research on Gender Differences in Math - National Council of Teachers of Mathematics," nctm.org, 09-May-2016. [Online]. Available:

https://www.nctm.org/Publications/Teaching-Children-Ma thematics/Blog/Current-Research-on-Gender-Differences-i n-Math/. [Accessed: 31-Mar-2020].

[39] J. T. Ajai and B. I. Imoko, "Gender Differences in Mathematics Achievement and Retention Scores: A Case of Problem-Based Learning Method," Int. J. Res. Educ. Sci., vol. 1, no. 1, pp. 45-50, 2015.

[40] C.-Y. Lee and H.-Y. Kung, "Math Self-Concept and Mathematics Achievement: Examining Gender Variation and Reciprocal Relations among Junior High School Students in Taiwan," EURASIA J. Math. Sci. Technol. Educ., vol. 14, no. 4, pp. 1239-1252, Jan. 2018.

[41] R. Heidari and F. Rajabi, "An Investigation of the Relationship between Mathematics Performance of Students in a Non-Routine Problem, according to Grade and Gender," Int. J. Innov. Sci. Math. Educ., vol. 25, no. 3 , 
pp. 11-19, 2017.

[42] B. Lefa, "The Piaget Theory of Cognitive Development: An Educational," no. September, 2014.

[43] R. . Hake, “Analyzing Change/Gain Score,” 1999.

[44] C. Stewart et al., "Biological Gender Differences in Students' Errors on Mathematics Achievement Tests," $J$. Psychoeduc. Assess., vol. 35, no. 1-2, pp. 47-56, Feb. 2017.

[45] O. Josiah and E. O. Adejoke, "Effect of Gender, Age, and Mathematics Anxiety on College Students' Achievement in Algebra," in The Eurasia Proceedings of Educational \& Social Sciences (EPESS), 2014, pp. 57-61.

[46] M. Samuelsson and J. Samuelsson, "Gender differences in boys' and girls' perception of teaching and learning mathematics," Open Rev. Educ. Res., vol. 3, no. 1, pp. 1834, Jan. 2016.

[47] A. K. Arhin and A. K. Offoe, "Gender Differences and Mathematics Achievement of Senior High School Students: A Case of Ghana National College," J. Educ. Pract., vol. 6, no. 33, pp. 67-74, 2015.

[48] G. C. Leder, "Gender and Mathematics Education: An Overview," in Compendium for Early Career Researchers in Mathematics Education, ICME-13 Monographs., Springer, Cham, 2019, pp. 289-308.

[49] O. Matanluk, B. Mohammad, D. N. A. Kiflee, and M. Imbug, "The Effectiveness of Using Teaching Module Based on Radical Constructivism toward Students Learning Process," in Procedia - Social and Behavioral Sciences 90, 2013, pp. 607-615.

[50] S. Sharma, "Developing statistical literacy with Year 9 students: a collaborative research project," Res. Math. Educ., vol. 15, no. 2, pp. 203-204, Jul. 2013.

[51] T. Koparan and B. Güven, "The effect of project-based learning on students' statistical literacy levels for data representation," Int. J. Math. Educ. Sci. Technol., vol. 46, no. 5, pp. 658-686, Jul. 2015.

[52] E. Stacey and P. Garbic, "Teaching for Blended Learning: How is ICT Impacting on Distance and on Campus Education?," in International Federation for Information Processing, Volume 210, Education for the 21th Century-Impact of ICT and Digital Resources, 2006, pp. 225-234.

[53] F. Alonso, G. López, D. Manrique, and J. M. Viñes, “An instructional model for web-based e-learning education with a blended learning process approach," Blackwell Publishing Ltd, 2005.

[54] J. Bersin, The Blended Learning Book: Best Practices, Proven Methodologies, and Lessons Learned. New York: Wiley, 2004.

[55] K. Thorne, Blended Learning: How to Integrate Online and Traditional Learning. London: Kogan Page, 2003. 